\title{
HSO Managers Spokesperson Self-Efficacy (SSE) when Meeting the Media
}

\author{
Christian Jacobsson*, Lena Låstad and Maria Wramsten Wilmar
}

Department of Psychology, University of Gothenburg, S-40530 Gothenburg, Sweden

\begin{abstract}
The present study examined Human Service Organizations (HSO) managers' self-efficacy as spokespersons towards the Media and the relationships to managers' individual experience of being a spokesperson. The purpose of the study was also to examine what role the management teams play with regard to team effectiveness and team size. A scale for measuring Spokesperson Self-Efficacy (SSE) was developed and evaluated in order to carry out the study. Altogether 96 HSO managers belonging to 12 management teams answered a questionnaire containing GDQ scale 4 (team effectiveness), the SSE scale and a question about the level of experience of being a spokesperson. Team size was also measured. The result showed a strong relationship between experience of being a spokesperson and SSE, but no relations were found between team effectiveness or team size and SSE.
\end{abstract}

Keywords: Experience; Management team; Self-efficacy; Spokesperson; Team size; Media

\section{Introduction}

Managers in Human Service Organizations (HSO) are facing an increased amount of interest from journalists as spokespersons of their organizations since the demand for insight into these organizations has increased [1]. There are probably several reasons for this. Runsjö and Nilsson [2] points out that these organizations are often municipally driven and easier to look into than private companies. They are often seen as having authority - which it is the job of the Media to scrutinize. Another explanation could be that many of these organizations use the media as a channel for increasing their visibility to the public $[3,4]$.

The purpose of the present study was twofold. The first was to develop a self-efficacy scale that covers the task of managers' when they are spokespersons towards the Media (e.g. in interviews or press conferences); Spokesperson Self-Efficacy (SSE). Here in the context of HSO managers. The second purpose was to study the relationships between SSE and managers' experience of meeting the Media and what role the dynamics of their management teams play.

\section{Self-Efficacy}

According to Bandura [5] self- efficacy refers to an individual's perception of his or her capacity to perform a specific task [6], in this study the task of meeting the media, i.e. journalists, as a spokesperson. Self-efficacy is often used as a domain specific construct, meaning that an individual can have a high belief in the capability in one specific task such as holding a speech and low belief in the capability in such as writing. Bandura argued that self-efficacy is a domain specific construct, which has shown to be influencing a variety of behavioral outcomes [5]. However, beside task specific self-efficacy, the concept of generalized self-efficacy, i.e. one's estimate of one's fundamental ability to cope, perform and be successful have been studied. Earlier research has demonstrated that generalized self-efficacy is one of the most important predictors of work performance and work satisfaction [7].

\section{Spokesperson self-efficacy (SSE)}

Self-efficacy as a spokesperson meeting the Media and journalists has to our knowledge not been studied before. The definition of SSE was: the belief in ones capability of acting as a spokesperson towards journalists (i.e. preparing a good strategy for the meeting, creating good conditions for communication, sending a clear message and stay calm during the meeting). However, there are some related concepts media self-efficacy has been coined as a concept describing how people process information acquired from mass media. Hence it is about being a receiver of information, not a sender as an active spokesperson. Another related concept is leadership self-efficacy created a taxonomy for the content of leadership self-efficacy with 27 specific domains, were several are linked to the situation of being a spokesperson. For instance, communicate, convince and project credibility (i.e. to appear honest and believable to others).

\section{The role of experience}

Research has shown that earlier experience of a situation, especially when handled successfully, has an impact on self-efficacy in a wide range of settings and also that it is possible to train self-efficacy in various fields [5]. Petersdotter et al. [8] found in their study of students studying one semester abroad, away from home, that this experience contributed to an increased general self-efficacy, i.e. one's optimistic self-beliefs to cope with difficulties and to perform challenging tasks [9]. Further, a short course for nurses on handling difficult communication situations achieved significant improvements in self-efficacy with regard to communication skills [10]. Lastly, Bandura stated that enactive mastery experiences are the most important source of an individual's self-efficacy beliefs [11]. Even though mastery and experience are two different things, mastery is not possible without experience. Therefore, the first hypothesis was:

Hypothesis 1: Experience as a spokesperson correlates positively with SSE.

\section{The role of the management teams}

Team-based work has now become a common form of work structure in most HSO, also with regard to managers working as

*Corresponding author: Christian Jacobsson, Department of Psychology University of Gothenburg, Gothenburg, Sweden, Tel: +46 31 7864694; E-mail: christian.jacobsson@psy.gu.se

Received: September 09, 2018; Accepted: September 22, 2018; Published: September 29, 2018

Citation: Jacobsson C, Låstad L, Wramsten Wilmar M (2018) HSO Managers Spokesperson Self-Efficacy (SSE) when meeting the Media. Clin Exp Psychol 4: 198. doi: 10.4172/2471-2701.1000198

Copyright: () 2018 Jacobsson C, et al. This is an open-access article distributed under the terms of the Creative Commons Attribution License, which permits unrestricted use, distribution, and reproduction in any medium, provided the original author and source are credited. 
members of management teams. A work or a management team is according Kozlowsky and Ilgen [12] composed of two or more individuals who exist to perform organizationally relevant tasks, share one or more common goals and exhibit task interdependencies (i.e., workflow, goals, knowledge and outcomes). Furthermore, they interact socially, maintain and manage boundaries, and are embedded in an organizational context.

This study uses the Integrated Model of Group Development (IMGD) and the linked instrument Group Development Questionnaire (GDQ) [13] as a way of describing and measuring team effectiveness. The model is an integration of earlier theory and research on team development across time. The validity of the IMGD and GDQ with regard to teams' performance has been established in a number of studies [13-15]. IMGD is a model describing four stages of group development. The stages are (I) dependency and inclusion, (II) counter-dependency and fight (III) trust and structure and (IV) work and productivity.

In the present study team effectiveness is defined as the degree to which a team cooperates in accordance with the fourth stage in IMGD, work and productivity. Therefor that stage is describe more thoroughly. Stage IV teams have established a team climate of openness and cohesion that facilitates effective work. Members are clear about goals and roles of the team, they are highly task-oriented most of the time and highly cooperative. In addition to the validity of IMGD with regard to team performance a number of studies have been conducted on its relation to different experiences of team members. For instance, the more effective team work - the lower levels of emotional exhaustion and higher levels of work satisfaction among team members $[16,17]$. Further, the more effective team work - the more feelings of mastery $[18,19]$. Feelings of mastery [20] is a concept describing individuals sense of mastering their work tasks when the combination of work demands and work control is promoting growth. Feelings of mastery is a construct describing the effect of the right conditions, and it has similarities to generalized selfefficacy even though it is a more internalized phenomena, describing one's beliefs about the own capability. Therefore, the second hypothesis was:

Hypothesis 2: Being a member of an effective management team correlates positively with SSE.

\section{The Effect of Team Size}

As Hare [21] pointed out over 60 years ago, members of large groups have less time to speak then members of small groups and that the more limited interaction in larger groups increases the members feelings that their opinions are not important and therefore not worth presenting in the group. Team size is an important structural variable influencing both team process, as described above, and team performance [2224]. Previous studies have shown that team size has a negative relation to individuals work satisfaction, perceived well-being and a positive relation to absenteeism [25-27]. Indicators of a relationship between team size and performance have been found. Mueller [28] concluded in a study on team size and individual performance that larger teams diminish perceptions of available support that otherwise would buffer stressful experiences and promote task performance. Furthermore, Watson et al. [29] found in a study on collective efficacy, i.e. team members shared beliefs in the team's capability to perform well, that individual's self-efficacy has a positive correlation with collective efficacy, which has a negative correlation with team size. Based on this, the third hypothesis was:

\section{Hypothesis 3}

Being a member of a larger management team correlates negatively with SSE.

\section{Method}

\section{Participants and context}

The participants in the present study were members of management teams in a convenient sample. In total, 96 individuals belonging to 12 management teams filled in and returned the questionnaire, for a response rate of $100 \%$. The researchers meet all participants face-toface at their management team meetings. The size of the management teams varied from 4 to 13 members, with an average of 8 members. The participating management team members came from three types of Human Service Organizations. They were leading Elementary schools, Municipal healthcare and Health Care organizations (Table 1).

All respondents were asked whether they have been a spokesperson in meeting with a journalist. The analyses in the present study are based on data from the 75 respondents who confirmed they have made this experience. Of these respondents, $71 \%$ were women. The average organizational tenure for the effective sample was 3.6 years.

\section{Measures}

Number of group members. Since the response rate was $100 \%$, the size of the management teams was measured by counting the number of completed questionnaires in each management team.

Frequency of media contacts. The respondents were asked how common it is for them to be a spokesperson for the organization in the media. Their responses were on a 3-point scale ranging from $1=$ not that common, to $3=$ very common.

Group Development Questionnaire, subscale 4 Group development was measured by a 15-item scale [13] and is one of 4 scales in GDQ, scale 4 is measuring the occurrence of effective cooperation in a team and is validated as linked to stage 4 in the integrated model of group development; Work and productivity. The Swedish translation of the original questionnaire items has been part of several studies $[16,17,30]$ and subscale 4 has also been used earlier as a measure of effectiveness of cooperation [31]. Example items are: The group gets, gives, and uses feedback about its effectiveness and productivity; The group acts on its decisions; This group encourages high performance and quality work. Responses were given on a Likertscale ranging from $1=$ never true for this group to $5=$ always true for this group. Cronbach's alpha for the scale is 0.87 , mean value and standard deviation in a Swedish sample with 764 groups are 54.7 (6.3) [17].

Spokesperson Self-Efficacy, SSE. Perceived self-efficacy in handling media contacts was measured with a 5-item scale developed for the

\begin{tabular}{|c|c|c|c|}
\hline & \multirow{2}{*}{$\begin{array}{c}\text { Management } \\
\text { teams }\end{array}$} & Respondents & $\begin{array}{c}\text { Experience being } \\
\text { spokes-person } \\
\text { (percentage of } \\
\text { respondents) }\end{array}$ \\
& & & $32(76 \%)$ \\
\hline Municipal & 6 & 42 & \\
\hline healthcare & & & $27(82 \%)$ \\
\hline Elementary & 3 & 33 & \\
\hline school & & & $16(76 \%)$ \\
\hline Healthcare & 3 & 21 & $75(78 \%)$ \\
\hline Total & 12 & 96 & \\
\hline
\end{tabular}

Table 1: Number of management teams and respondents. 
purpose of this study. The questions were (1) I can arrange a meeting with media that provides good conditions for me to get my message across (2) I'm sure I can feel calm during my meeting with the media (3) I can create the conditions for a constructive meeting with the media (4) I can prepare a good strategy for my meeting with the media (5) I can be clear in my meeting with the media. Response options were on a 10 -point Likert scale ranging from $0 \%=\mathrm{I}$ don't feel confident to $100 \%=I$ feel very confident. The scale showed good internal consistency $(\alpha=0.94)$, and the questions formed a single factor in an exploratory factor analysis (EFA), with factor loadings ranging from 0.77 to 0.95 , well above the recommended threshold at 0.75 for small samples [32].

\section{Analysis}

Descriptive analyses, exploratory factor analysis and multiple regression analysis were conducted in IBM Statistics SPSS 24.

\section{Results}

Pearson correlations, means and standard deviations for the study variables are reported in Table 2 . The results show a significant correlation between the level of experience frequency of media contacts and SSE $(r=0.50, \mathrm{p}<0.01)$. The results of the multiple regression analysis are reported in Table 3 .

\begin{tabular}{|l|c|c|c|c|c|c|}
\hline & & $\mathbf{M}$ & SD & $\mathbf{1 .}$ & $\mathbf{2 .}$ & $\mathbf{3 .}$ \\
\hline 1. & Number of group members & 8,00 & 2,66 & & & \\
\hline 2. & Frequency of media & 1,28 & 0,69 & 0,08 & & \\
\hline & contacts & & & & & \\
\hline 3. & GDQ 4 & 54,41 & 7,41 & $-0,24^{*}$ & $-0,09$ & \\
\hline 4. & SSE & 6,4 & 2,07 & 0,04 & $0,50^{* *}$ & 0,01 \\
\hline
\end{tabular}

Note: $\mathrm{N}=82 .{ }^{*} \mathrm{p}<0.05 ;{ }^{* *} \mathrm{p}<0.01$

Table 2: Descriptive statistics and correlations of the study variables.

\begin{tabular}{|c|c|}
\hline Independent variables & B \\
\hline Number of group members & 0.01 \\
\hline Frequency of media contacts & $0.50^{* *}$ \\
\hline GDQ 4 & 0.05 \\
\hline $\mathrm{R}^{2}$ (adjusted) & 0.22 \\
\hline
\end{tabular}

Note: $\mathrm{N}=82$. ${ }^{* *} \mathrm{p}<0.01$.

Table 3: Multiple regression analysis with SSE as the dependent variable. Standardized beta-coefficients.

The results of the multivariate analysis mirrors the bivariate correlations, in that frequency of media contacts was the only significant independent variable (beta $=0.50, \mathrm{p}<0.01$ ). The total variance in SSE explained by the model was $22 \%$.

\section{Discussion}

The first purpose of the present study was to developing a selfefficacy scale that focuses on the task of being a spokesperson towards the Media (e.g. in interviews or press conferences). The definition of self-efficacy during media encounters that was departed from in this study was; the belief in one's capability of acting as a spokesperson towards journalists, creating good conditions for communication and sending a clear message. The 5-item scale developed for the present study formed a single factor in an exploratory factor analysis and the scale showed a good internal consistency. The SSE scale can therefore be used in a future validation study.

The second purpose was to study the relationship between SSE and individual experience as a spokesperson, the dynamics of the management team and the size of the team. 75 respondents out of 96 (78\%) of the managers who participated in this study had experience of being a spokesperson towards media representatives. The analyses were based on those 75 managers.

Hypothesis 1: Experience as a spokesperson correlates positively with self-efficacy as a spokesperson.

As shown in Table 3, the result of the multiple regression analysis points to a very strong positive relationship between degree of earlier experience of being a spokesperson and SSE. Having experience has shown to be strongly linked to self-efficacy in earlier research. Both with regard to general self-efficacy [8] and concerning task specific selfefficacy such as nurses communication skills [10]. The present results are also partly contradicting two studies of Wramsten Wilmar et al. [33,34]. These studies did not indicate that managers become more secure in their encounters with media just because they had much experience of the situation. It could also go the other way, becoming more insecure. However, both the mentioned studies concerned managers who were spokespersons when media made critical reviews of their organizations. The present study has another inclusion criterion; the managers could refer to positive, negative or neutral media exposure. Hence, this might explain the difference between the present study and the two mentioned, negative exposure probably brings about negative experience, which in turn could decrease security and loss of mastery the next time.

As Bandura stated, enactive mastery experiences are the most important source of an individual's self-efficacy beliefs [11].

Another aspect that is important to take into consideration in relation to this study is the results of Wramsten Wilmar et al. [34], which showed that the managers included in their study found it difficult to assess their own reactions during media focus. Wramsten Wilmar et al. [34] showed that the people around the manager such as their superior manager, colleagues, partners or subordinates etc. found it easier to describe the managers' reactions and support resources. The question is what results this study had shown if the people around the managers in this study had answered the questions about how they had perceived the managers' level of self-efficacy being a spokesperson?

The managers in Wramsten Wilmar et al. [33] and Wramsten Wilmar et al. [34] described that they ought to manage challenging situations on their own and that they risk being perceived as weak and inadequate if they ask for help. This fear of being seen as inadequate may have influenced how the respondents filled out the surveys on self-efficacy in this study, even though information about respondent anonymity was provided when the surveys were handed out. Perhaps more experienced managers want to claim feeling more secure when meeting the media?

Hypothesis 2: Being a member of an effective management team correlates positively with self-efficacy as a spokesperson.

Hypothesis 2 was rejected. The result shows a small and nonsignificant correlation between GDQ scale 4 , which reflects effectiveness in management team cooperation, and spokesperson self-efficacy. Also, no relationship was found in the multiple regression analysis. The results are surprising since effective team work, measured by GDQ scale 4 has shown to have significant correlations to several other output measures, for instance the more effective team work - the more feelings of mastery among team members [19].

A Previous study [33] has shown that managers do not expect to 
receive any support in connection to being a spokesperson towards the media. The managers in the mentioned study perceived that they were expected to act as the spokesperson themselves, without any support from managerial colleagues. This expectation might to some extent explain the results of the present study. When you don't expect the management team to partake in the responsibility or provide support during interactions with the media the effectiveness of the management team is of no relevance for the individual managers' self-efficacy as spokesperson. Task interdependence is an important characteristic of effective team work, when work is carried out together as a team [35]. But if being a spokesperson is seen as an individual task, implying low degree of task interdependence, the effectiveness of the management team becomes of low importance with regard to managers self-efficacy as spokespersons.

Hypothesis 3: Being a member of a larger management team correlates negatively with self-efficacy as a spokesperson.

This hypothesis was also rejected. The result showed there was a negative correlation between size of the management team and GDQ scale 4 , effectiveness in cooperation, but there were no relation to spokesperson self-efficacy. Also, no relationship was found in the multiple regression analysis. On a more general level, previous research has pointed out a relationship between team size and performance. Mueller [28] concluded in a study on team size and individual performance that larger teams diminish perceptions of available support that otherwise would buffer stressful experiences and promote task performance. Furthermore, Watson et al. [29] found in a study on collective efficacy that individuals self-efficacy has a positive correlation with collective efficacy, which has a negative correlation with team size. The most plausible explanation to the lack of relationship between team size and SSE is probably the same as for hypothesis 2 . An earlier study Wramsten Wilmar et al. [33] showed that managers do not expect to receive any support in connection to being a spokesperson towards the media, regardless of management team size. They thought they were expected to act as the spokesperson themselves, without any support.

\section{Limitations}

The present study was limited by its' relatively small sample and the lack of knowledge about the validity of the SSE scale developed for the present study. However, the reliability of the scale was satisfying. A future validation study is recommended. A possible way to carry out such a study could be by inviting experts on communication in interviews or press conferences that will assess the performance of managers in combination with their answers on the SSE scale.

\section{Conclusion}

The present study examined HSO managers' self-efficacy as spokespersons towards the Media. The results indicated that the level of experience regarding being a spokesperson has a strong relationship to the degree of Spokesperson self-efficacy, but the effectiveness of management teams or the size of those teams doesn't seem to play any role in this context.

\section{Disclosure Statement}

No potential conflict of interest was reported by the authors.

\section{References}

1. Johansson S, Dellgran P, Höjer S (2015) Människobehandlande organisationer Villkor för ledning, styrning och professionellt välfärdsarbete: Natur \& Kultur, Stockholm.
2. Runsjö F, Nilsson KO (2009) Mediedrev 2.0: handbok i överlevnad. Blue Publishing, Stockholm.

3. Strömbäck J (2004) Den medialiserade demokratin: om journalistikens ideal, verklighet och makt (Vol. 1. uppl.). Stockholm: SNS förl.

4. Strömbäck J (2014) Makt, medier och samhälle: en introduktion till politisk kommunikation (Vol. 2.uppl.). Lund: Studentlitteratur.

5. Bandura A (1997) Self-efficacy: the exercise of control. Freeman WH Basingstoke: Basingstoke.

6. Gist ME, Gist A (2013) Self-Efficacy: Oxford University Press.

7. Judge TA, Bono JE (2001) Relationship of Core Self-Evaluations Traits-SelfEsteem, Generalized Self-Efficacy, Locus of Control, and Emotional StabilityWith Job Satisfaction and Job Performance: A Meta-Analysis. J Appl Psychol 86: 80-92.

8. Petersdotter L, Niehoff E, Freund PA (2017) International experience makes a difference: Effects of studying abroad on students' self-efficacy. Pers Individ Dif 107: 174-178.

9. Schwarzer R, Jerusalem M (1995) Self-efficacy measurement and generalized self-efficacy scale. In Weinman J, Wright S, Johnston M (editors), Measures in health psychology: A users's portfolio. Causal control beliefs (pp. 33-39). Windsor: NFER-NELSON.

10. Doyle D,Copeland HL, Bush D, Stein L, Thompson S (2011) A course for nurses to handle difficult communication situations. A randomized controlled trial of impact on self-efficacy and performance. Patient Educ Couns 82: 100-109.

11. Bandura A (1986) Social foundations of thought and action: A social cognitive theory. Englewood Cliffs, NJ. : Prentice-Hall.

12. Kozlowski SWJ, Ilgen DR (2006) Enhancing the Effectiveness of Work Groups and Teams. Psychol Sci Public Interest 7: 77-124.

13. Wheelan SA, Hochberger JM (1996) Validation Studies of the Group Development Questionnaire. Small Group Res 27: 143-170.

14. Wheelan SA, Davidson B, Tilin F (2003) Group Development Across Time: Reality or Illusion? Small Group Res 34: 223-241.

15. Wheelan SA, Mckeage RL (1993) Developmental Patterns in Small and Large Groups. Small Group Res 24: 60-83.

16. Jacobsson C, Rydbo N, Börresen JE (2014) The Links Between Group Development and Health in Manufacturing Industry. Small Group Res 45: 400-415.

17. Jacobsson C, Åkerlund M, Graci E, Cedstrand E, Archer T (2016) Teacher team effectiveness and teachers' wellbeing. Clin Exp Psychol 2: 130.

18. Jacobsson C (2013) Group Development and health in Schools - A pilot study. Paper presented at the Work Group Development: Theory, Research \& Practice, Saint Joseph's University, Philadelphia, PA.

19. Rydbo N, Børresen JE, Jacobsson C (2013) The relationship between group dynamics and health in Swedish manufacturing industry. Paper presented at the Work Group Development: Theory, Research \& Practice, Saint Joseph's University, Philadelphia, PA.

20. Karasek R, Theorell T (1990) Healthy work: stress, productivity, and the reconstruction of working life. New York, NY. : Basic Books, Newyork.

21. Hare AP (1952) A Study of Interaction and Consensus in Different Sized Groups. Am Sociol Rev 17: 261-267.

22. Hackman JR (1987) The design of work teams. In J Lorsch (Ed.), Handbook of organizational behavior. Englewood Cliffs, NJ: Prentice-Hall.

23. Hoegl M (2005) Smaller teams-better teamwork: How to keep project teams small. Bus Horiz 48: 209-214.

24. Wheelan SA (2009) Group Size, Group Development, and Group Productivity Small Group Res 40: 247-262.

25. Aubé C, Rousseau V, Tremblay S (2011) Team Size and Quality of Group Experience: The More the Merrier?. Group Dynamics: Theory, Research, and Practice 15: 357-375

26. Markham SE, Dansereau F, Alutto JA (1982) Group Size and Absenteeism Rates: A Longitudinal Analysis. Acad Manage Rev 25: 921-927. 
Citation: Jacobsson C, Låstad L, Wramsten Wilmar M (2018) HSO Managers Spokesperson Self-Efficacy (SSE) when Meeting the Media. Clin Exp Psychol 4: 198. doi: 10.4172/2471-2701.1000198

Page 5 of 5

27. Wegge J, Roth C, Neubach B, Schmidt KH, Kanfer R (2008) Age and Gender Diversity as Determinants of Performance and Health in a Public Organization: The Role of Task Complexity and Group Size. J Appl Psychol 93: 1301-1313.

28. Mueller JS (2012) Why individuals in larger teams perform worse. Organizational behavior and human decision processes. A journal of fundamental research and theory in applied psychology 117: 111-124.

29. Watson CB, Chemers MM, Preiser N (2001) Collective Efficacy: A Multilevel Analysis. Pers Soc Psychol Bull 27: 1057-1068.

30. Wheelan SA, Jacobsson C (2014) A Descriptive Study of Work Groups in the Swedish and U.S. Economy. Paper presented at the the 9th GRASP conference, Linköping: Linköping University.

31. Gren L, Torkar R, Feldt R (2017) Group development and group maturity when building agile teams: $A$ qualitative and quantitative investigation at eight large companies. J Syst Softw 124: 104-119.
32. Hair JF, Black WC, Babin BJ, Anderson RE (2014) Multivariate data analysis (Seventh edition, Pearson new international edition. ed.). Harlow: Pearson Education Limited.

33. Wramsten Wilmar M, Ahlborg G, Dellve L, Tidefors I, Jacobsson C (2017) Swedish Healthcare Managers and the Media - A Study of Strategies and Support During Mass Media Attention. Scandinavian Journal Of Work And Organizational Psychology 2: 1-10.

34. Wramsten Wilmar M, Ahlborg G, Jacobsson C, Dellve L (2014) Healthcare managers in negative media focus: a qualitative study of personification processes and their personal consequences. BMC Health Serv Res 14: 1-12.

35. Katz-Navon TY, Erez M (2005) When Collective- and Self-Efficacy Affect Team Performance: The Role of Task Interdependence. Small Group Res 36: 437-465. 